\begin{tabular}{|c|c|c|}
\hline Received 14.10.2019 & \multirow{3}{*}{ Research Article } & \multirow{3}{*}{$\begin{array}{c}\text { JOTS } \\
5 / 1 \\
2021: 146-160\end{array}$} \\
\hline Accepted 12.08.2020 & & \\
\hline Published 10.01.2021 & & \\
\hline
\end{tabular}

\title{
Kırcali Ağzı Örneğinde Doğu Rumeli Ağzının Batı Anadolu Bölge Ağzı ile İlişkisi ${ }^{*}$
}

\section{On the Basis of Kircali the Eastern Rumeli Dialect in Connection with Western Anatolia Region Dialect}

\author{
Sultan Tulu** \\ Muğla/Turkey \\ E-mail:sultantulu@yahoo.com
}

On the connection of the Kircali (Gircalı) sub-dialect with the dialect of Western Anatolia -based on the data of the present tense suffix of Meninski- Adamovic firstly drew attention. According to the available data, the Western-Anatolian region is not far from the dialects of the middle Deliorman Region. As an example, we can show Edirne-Dağlı dialect, which is located at the dialect of East-Rumelia region. For example: $\{-(\mathrm{I}) \operatorname{vAr}(\mathrm{I})\}$ which is shown as a present tense suffix. In this study, on the basis of Kircali (Kardzhali) Dialect, the connection of Eastern Rumeli Dialect with Western Anatolian Dialect will be compared with certain language criteria and common elements will be revealed.

Key Words: Kircaali dialect, Western Anatolian dialect, Eastern Rumeli dialect, present tense suffix $\{-(\mathrm{I}) \operatorname{vAr}(\mathrm{I})\}$.

\footnotetext{
* Makale, Trakya üniversitesinde düzenlenen 4. Uluslararası Türkiye Türkçesi Ağız Araştırmaları Çalıştayı'nda (Edirne, 2011) sunulan bildirinin yeniden gözden geçirilip düzenlenen şeklidir.

** ORCID ID: 0000-0002-8851-7738.
} 


\section{ग(৫)}

\section{Giriş}

Anadolu ve Rumeli ağızları, Türkiye Cumhuriyeti sınırları içinde, Türkiye Türkçesi yazı dilinden ses bilgisi, şekil bilgisi özellikleri ve söz varlı̆̆ı açısından birçok yönde ayrilıklar gösteren bir ağızlar topluluğudur. Tarihi gelişme sürecinde Oğuzca'nın son halkasını oluşturur. Dil yapısı bakımından temel dayanağı Eski Anadolu Türkçesidir (Korkmaz, 2010: 87-110). Türkiye Türkçesi başta olmak üzere güneybatı Türk lehçelerinin oluşmasında temel görev yüklenen Oğuz Türkçesi, ilk kez bu dönemde Anadolu ve Rumeli bölgesinde kendi başına bir yazı dili olma niteliğindedir. Korkmaz’a göre, Eski Anadolu Türkçesi, XV. Yüzyılın ortalarından başlayarak iki yönlü bir değişim ve gelişim süreci izler. Birinci yöndeki değişim ve gelişmeler, bir süre belirli bir boy ağzı (muhtemelen Kayı boyu ağzı) doğrultusunda yol alır ve daha sonra Osmanlı Türkçesi evresinden geçerek günümüz Türkiye Türkçesi yazı dilini oluşturur. İkinci yöndeki değişim ve gelişme sürecinde ise, Eski Anadolu Türkçesi, konuşma dili ve ağız ayrılıkları doğrultusunda yol alır ve yazı dilinin etkisinden uzak kalarak günümüz Anadolu ve Rumeli ağızlarını oluşturur. Bu nedenle bugünkü Anadolu ve Rumeli ağızlarının temel dayanağı Eski Anadolu Türkçesidir.

L. Karahan'ın Anadolu ve Rumeli ağızları üzerinde dil özelliklerine dayanarak yapılan Anadolu Ağızları Sinıflandırlması adlı eserine göre, bu ağızlar, yapılarını belirleyen temel özellikler açısından, 1. Doğu Grubu ağızları; 2. Kuzey Doğu Grubu ağızları; 3. Batı Grubu ağızları olarak üç ana gruba ayrılmıştır. Bunlardan Batı Grubu ağızları da dokuz alt gruba ayrılmıştır. Bunların ayrıca ikinci derecede alt gruplara ayrılmaları, bu ağızlar arasında ne denli bir dil çeşitlenmesi olduğunu gösterir. Korkmaz’a göre bu farklılıklar, Kıpçak, Çiğli, vb. Oğuz dışı Türk etnik boylarının Anadolu içinde karışıp harmanlanmasından kaynaklamaktadır. Oğuzca, Anadolu'nun fethinden sonra, bu coğrafyadaki yerli dillerden bazı kelimeler ve yapım ekleri almıştır. İç yerleşimdeki karşılıklı etkileşim sonucunda ve 500-600 yıllık tarihi süreçte yazı dilinden uzak kalan bu ağızlar, kendi yapısında birbirinden farklı ses değişmeleri geçirmiştir. Bu gelişme ve sonuçlar dikkate alınınca, Anadolu ve Rumeli Ağızlarında kendini gösteren bu çeşitlilik ve zenginliğin temelinde hangi nedenlerin yattığı anlaşılır (Korkmaz, 2008).

Bulgaristan, Balkan coğrafyasında Türklerin yoğun olarak yaşadıkları ülkelerden birisidir. Bu ülkede Türkler, yaşadıkları bölgeye göre, Rodop 


\section{ग(৫)}

Balkanları adıyla da anılan Rodop bölgesi ile Deli Orman Bölgesi (Razgrad, Eski Cuma, Şumnu) ve diğer Türk yerleşim bölgelerinde yaşamaktadırlar. Bu çalışmada ele aldığımız Kırcali (halk ağzında Gırcall) ağzı da Bulgaristan'da konuşulmaktadır. Kırcali, Bulgaristan'da Rodop bölgesinin merkezinde, adını Kırcı Ali denilen bir kişiden almış şehrin adıdır. Gerileyici ünlü benzeşmesi ile ad Kırcl Ali'den Kırcali'ye dönüşmüştür. Tarihi süreç içinde buralara Türk kavimlerinden Hunlar, Peçenekler ve Kumanlar gelmiş, farklı devirlerin ve kültürlerin izlerini korumuştur. Kırcali, Traklar'ın, Roma ve Bizans medeniyetlerinin, Osmanlı hâkimiyetinin izlerini taşır. Buraya bağlı 94 köy bulunur; bunların yüzde doksan altısı Türk köyleridir. Ancak geçit yeri olmadığından dolayı fazla gelişmemiştir. Burada bulunan tarihî tekke, türbe ve camilerin olması, Müslüman Türk unsurunun yüzlerce yıl öncesinden varlı̆̆ını gösterir. Şehir üzerinde ilk yazılı kaynak Osmanlı dönemine ait 1607 tarihli sicil defteridir. İkinci olarak şehrin adı, Fransız araştırmacı A. Vinekel'in 1847 yılında tuttuğu notlarda kaydedilmiştir. Kırcali, XX. yüzyılın başında şehir olarak ilân edilmiş, 1934 yılından itibaren ilçe, 1949'dan sonra ise sancak olmuştur. Günümüzde Kırcali, yedi Doğu Rodop belediyesinin kültürel, idarî ve iktisadî merkezidir. Kırcali ilinden Baltık Denizi ile Akdeniz arasındaki ulaşımı sağlayan 9 numaralı Avrupa ulaşım koridoru geçmektedir. Ulaşım konusunda 9 numaralı koridorun Makaza yolundan geçerek Kırcali ile Ksanti şehri (Yunanistan) arasındaki ve Dedeağaç ile Kuzey Yunanistan'ın diğer şehirleri arasında ulaşımı sağlayarak, Güney Balkanlar'da bölgesel önem taşıması beklenmektedir (Krş. Mehmed, 2006).

Bulgaristan'da konuşulan ağız toplulukları, Doğu Rumeli ağız grubuna girmektedir. Kırcali ağzının, Batı Anadolu bölge ağzı olan Muğla ağzı ile bağlantısına geçmeden önce Bulgaristan'daki diyalektoloji çalışmaları hakkında aşağıda genel bilgi vermek istiyoruz.

\section{Bulgaristan'daki Diyalektoloji Çalışmaları}

Bulgaristan'da Türk diyalektolojisi Bulgar Türkolog D. Gadjanov'un araştırmalarıyla başlar. Viyana Bilimler Akademisi'nin isteği üzerine Gadjanov, Gerlovo ve Tuzluk köylerini gezerek orada konuşulan Türk ağızlarından örnekler toplar. Bu diyalektoloji gezisinin sonuçlarını 1911 yılında Viyana'da yayımlar. (1912: 1-8; Dall1, 1991). Rus bilgini V. G. Guzev, Bulgaristan Tırgovişte ilinin 
Krepça köyü Türk ağzıyla ilgilenir. Onun bu konudaki çalışmaları 1961 yılında Sofya'da yayımlanır (1962: 57-85). Diyalektoloji alanında önemli yapıtları bulunan bir başka Türkolog da T. Kowalski'dir. Rumeli Türk ağızlarının özgün bir biçimde incelenmesi onun araştırmalarıyla başlar. O, Kuzeydoğu Bulgaristan'ın Tuzluk bölgesinde konuşulan Türk ağızlarının özelliklerini inceler (1933). Mollova, bir çalışmasında Balkan Yarımadasında konuşulan Türk ağızlarını "ka ve ga ağızları" olarak ele alır (1962: 239-306). Eckmann, Razgrad Türk Ağzı adıyla kaleme aldığı kitapçı şeklindeki monografisinde, bölgeden derlediği metinlerden istifade ederek bu ağzın özelliklerini inceler. Aynı yazar, Dinler (Makedonya) Türk Ağzı ve Kumanova (Makedonya) Türk Ağzı isimli çalışmalarını yayımlar (1950: 1-25; 1962; 1988: 189-204). Razgrad ağzıyla yapılmış diğer bir çalışma, F. Ayyıldız'a aittir (1976).

B. Roger'in Bulgaristan Razlog ilçesi diyalekti ile ilgili bir çalışması vardır (1962: 205-229). Bunlara Bulgaristan Sofya Üniversitesi öğretim üyesi E. Boev'in Bulgaristan'da Türk Diyalektolojisi İle İlgili Çalışmaları adlı makalesini (1968: 171-177; 1978) ve Hazai'in Rodop Türk Ağızları'nı ekleyebiliriz (1960: 127-130). G. Hazai, 1954 yılında hocasi J. Németh'in önerisi üzerine-, Balkanlar'daki Türkoloji çalışmalarına katılır ve Rodop Türk ağızlarını incelemeye başla. 1957 yılında VIII. Türk Dil Kurultayı'na Rodop Türk Ağızları adını taşıyan bir bildiriyle katılmıştır. Bu bildiride Rodop Türk ağızlarının bölgesel yerleşimini göstermiş, örneğin Asenovgrad, Peştera, Nevrokop, Kırcali, Momçilgrad yörelerindeki Türk ağızlarını Rodop ağızları olarak belirlemiştir. Ayrıca Kuzeydoğu Bulgaristan ağızlarıyla Rodop ağızları arasında önemli yakınlıkların bulunduğuna değinen Hazai, bu ağızların tek bir ağız bölgesi sayılabileceğini ileri sürmüştür. Benzer bir görüşü daha önce T. Kowalski de savunmuş, bu ağızları Tuna Türkçesi diye adlandırmıştı. Kuzeydoğu Bulgaristan Türk Ağızları uzmanı Hüseyin Dallı'nın ise bu konuda bize yazılı olarak bildirdiği görüş şöyledir:

Rodop Türk ağızlarının Tuna Türkçesi diye adlandırılan ağız kümesinde bir alt bölüm oluşturabileceği savı birkaç noktadan eleştirilebilir. Bugün bu iki ağzın benzerliği sürmekle beraber ileri sürülen terimin bilimsel kullanımı yaygın değildir. Tuna Türkçesi coğrafya açısından da eleştiri götürür. Belki Kuzeydoğu bölge ağızları için Tuna'ya yakın olmaları nedeniyle bu terim uygun düşebilir, ama başka yörelerdeki ağızlar için bu coğrafya bağıntısını kuramayız. Öte yandan Rodop ağızlarının Kuzeydoğu Bulgaristan'dan göç etmiş halklarca kullanıldığı gibi bir sav olmadığından ve üstelik bu iki grubun bulundukları yerlere çoğunlukla değişik zamanlarda ve değişik yörelerden geldikleri bir tarihi gerçeklik 
olduğuna göre, bu iki yöre ağzı bir kümeye konulabilse bile, bunlara beraberce Tuna Türkçesi denemez." (1991: 9).

J. Eckmann ve Mecdut Mansuroğlu'nun birlikte kaleme aldıkları 1959 Yll Trakya diyalektolojisi Gezi Raporu, Doğu Trakya ağızları ile Balkan ülkelerindeki çeşitli Türk ağızlarını ayrıntılı olarak karşılaştırır. J. Eckmann’ın Bulgaristan Türk Ağızları ile ilgili Varna Türk Ağzı adlı çalışması, ayrıca Edirne Türk Ağzı makalesi vardır (1959: 113-118; 1941: 144-214; 1962: 45-69). Buna Cengiz Atilla'nın Bulgaristan'da Türk Dili adlı makalesini de ekleyebiliriz (1967: 847-852).

Türkiye'de Rumeli ağızları ile Anadolu ağızları arasındaki ortaklık ve akrabalık üzerine yapılan çalışmalardan biri de Metin Karaörs'ün Kuzeydoğu Anadolu (Trabzon ve Yöresi) ve Batı Rumeli Türk Ağızlarının Ortaklı̆ı ve Akrabalı̆ı adlı makalesidir. Yeni çalışmalardan Doğu Rumeli'nin Türkiye ayağı olan Doğu-Trakya Ağızlarının Şekil Bilgisini Belirleyen Temel Özellikler çalışmasıyla A. Günşen'i anabiliriz.

Bibliyografya olarak, T. Acaroğlu'nun Rumeli Türk Ağızları Üzerine Türkçe Ve Yabancı Dillerdeki Başlıca Araştırmaların Açıklamalı Kaynakçası (1984: 13-40) adlı makalesi ve T. Gülensoy ile E. Alkaya'nın Türkiye Türkçesi Ağıları Bibliyografyası adlı çalışmayı (2003: 155-188; Gülensoy, 1981) ve sözlük çalışması olarak dil bilimci M. Moskov'un Doğu Rodop Türk Ağızlarının Sözlüğü'nü ekleyebiliriz. Mollova bu sözlüğü Türkiye Türkçesine kazandırmıştır. (Mollova 2003). ${ }^{1}$

Bunlardan başka Bulgaristan'da konuşulan ağızlar hakkında Türkiye'de birçok lisans tezi yaptırılmıştır (Mehmed, 2006; Çebi, 1986; Ali, 2004). Bu yazıda, kendisi de Bulgaristan'ın Kırcali bölgesinden gelen N. S. Mehmed'in adı geçen çalışmasından faydalandık.

\section{Sinıflandırma Üzerine}

Anadolu ve Rumeli ağızları üzerine değişik sınıflandırmalar yapılmıştır. Bunun için de araştırmacılar belli ölçütlerden hareket etmişlerdir. E. Boev, Bulgaristan'daki Türk ağızlarının bütünüyle incelenmemesine rağmen onun üç bölümde ele alınabileceğini ifade eder: 1. Batı Balkan ağızları; 2. Miziya ve Trakya

\footnotetext{
H. Dallı'dan aldığımız sözlü bilgiye göre, Moskov'un ayrıca yansımalı ve yansımasız Türkçe kelimeler üzerine yaptı̆̆ı derlemeler vardır. (Örneğin, Fa. havan, Tü. çangal v.b. gibi kelimelerin kökenini açıklamıştır.); Moskov'un bu ve diğer çalışmaları için bk. Dallı'nın baskıdaki eseri.
} 


\section{1(0)}

ağızları ve 3. Doğu Rodop, Gerlovo ve Tuzluk ağızları. E. Boev'e göre bu üç bölümün dışında Orta Rodop ve Yörük ağızları, Balkan Türk ağızları arasında ayrı bir yer tutmaktadır. H. Dallı'nın verdiği bilgiye göre, E. Boev'in ders notlarındaki bu sınıflandırması genellikle kabul gören sınıflandırmadır.

Bulgaristan Türk ağızları üzerinde çalışan diğer araştırmacılar, Gy. Németh, J. Eckmann, S. Kakuk, V.G. Guzev, G. Hazai'dir.

Macar Türkolog Gy. Németh, Rumeli Türk ağızlarını batı ve doğu olmak üzere iki ana kola ayırır. Doğu Rumeli ağızları Bulgaristan'ın Lom-SofyaSamokov-Köstendil-Ege denizi sahiline kadar uzanan hattın doğu ve güneyinde, Batı Rumeli ağızları da Lom-Samokov hattından batıya ve Samokov-KöstendilMakedonya hattından kuzeye doğru uzanan bölgede konuşulur (1983: 113-167).

Bu sınıflandırmada, Batı Rumeli (Makedonya ve Kosova) ağızları için sekiz ölçüt belirlenmiş̧ir. Németh, Batı Rumeli ağızlarını Doğu Rumeli ağızlarından ayıran özellikleri belli başlı sekiz maddede gösterir:

1. Birden fazla heceli kelimelerin sonunda /1/, /u/, /ü/ yerine /i/ bulunur: alti, kuzi, buldi, köpri, oldi, öldi vb.

2. Duyulan geçmiş zaman eki $\{-\mathrm{mX}$ ş\} yerine daima $\{$-miş\} ekinin kullanılır: almiş, okumiş, ölmiş vb.

3. İkinci, bundan sonraki ve kapalı son hecede /i/ > /1/ değişimi bulunur: benım, elinde, evimizde, evinde, verdım, vermışım vb.

4. Bazı hallerde /ö/ ve /ü/ yerine /ŏ/ ve /ŭ/ (o ile u arası ünlü) veya /o/ve $/ \mathrm{u} /:$ dort, gotur, yŭn vb.

5. /a/ ve /e/ vokalli eklerde, kalın vokalli kelimelere de /e/'li varyantların getirilerek büyük ünlü uyumunun bozulması: bakarler, taşler, varse, yalnızce, olunce, yavaşçe, agacden, kızlen, yaptıkten sonra veya daha az miktarda bunun tersi: sevma; gidalim, ben da vb.

6. illk hecede /ö/ > /ü/ ve /ŭ/, /u/ ses değişmesi: küpri kŭpri vb.

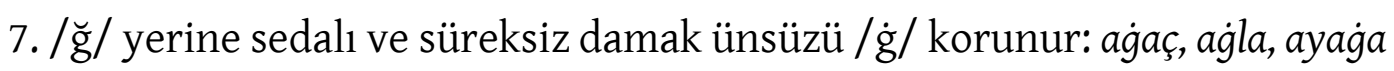
$\mathrm{vb}$.

8. Şimdiki zaman kipi için \{-yor\} eki yerine $\{-y\}$ 'nin kullanılması: sorayım, aglaysin, yapay, istey vb. (Németh, 1983: 121-128; Eckmann, 1988: 188-190) 
1. ve 2. maddede verilen örneklerde kelimelerin eski şeklindeki ünlüler korunmuştur; zira küçük ünlü uyumu kuralı (düzlük yuvarlaklık uyumu) Türkçede sonradan gelişmiştir. 3. ve 4. maddede Slav dillerinin ağız etkisi olması mümkündür. 5. maddede kalınlık incelik uyumu Türkçeye aykırı olup Slavcanın etkisi burada daha belirgindir. (Küçük ünlü uyumu için bk. Dall, 1991: 76-77). Sekizinci maddeye aynı zamanda Doğu Rumeli ağızlarında da rastlanır. İ. Baski de, bir bildirisinde Batı Rumeli'de görülen \{-Ay\} ekinin Doğu Rumeli ağızlarında görüldüğünü belirtir. (2009).

Doğu Rumeli grubunda şimdiki zaman kategorisinin yirmiden fazla farklı şekli vardır: yapıyor, yapayor, yapıyı, yapēri vb. Mollova, şimdiki zaman eki ile ilgili olarak, bu eki oldukça değişken bir yapı göstermesinden ötürü tasnif dışında tutmuştur. Aynı görüşü $\mathrm{H}$. Dallı da paylaşmaktadır. Anadolu ağızlarının sınıflandırılmasında kullanılan ölçütlerde \{-iver\} şekli, diğer şimdiki zaman eklerinin yanında görülmez. L. Karahan, Z. Korkmaz, H. Boeschoten (1991: 154) bu eki, şimdiki zaman ölçütü olarak almamışlardır.

M. Mollova, Németh'in tetkiklerini dikkate alarak Balkan ağızlarını fonetik ve morfolojik ölçütllere göre üç zona (bölgeye) ayırmıştır: Batı uç zonu; Doğu Rodoplar zonu ve Merkez zon.

G. Hazai, Anadolu ve Rumeli ağızlarını sınıflandırmada, /y/, /l/, / $\breve{g} /$, /q/ ünsüzlerindeki ses değişmeleri, kalınlık-incelik, düzlük-yuvarlaklık bakımından uyumsuzluklar ve şahıs eklerinin yapısının ölçüt olarak kullanabileceğini söyler (Karahan, 1996: XII'den naklen Hazai, 1971: 84-86).

Anadolu ağızlarının sınıflandırmasında L. Karahan'ın çalışması, çok sayıda derleme ve incelemenin kaynaklık ettiği bir sınıflandırma denemesidir. Karahan, iki bölüme ayırdığı çalışmasının girişinde Anadolu Ağızlarının, tamamının veya bir kısmının ele alındığı sınıflandırma çalışmaları hakkında bilgi verir. İkinci bölümde ise, önce ağız grupları ve bu grupların ayırıcı özelliklerini tespit edip örneklendirir ve bu özelliklerin coğrafi dağılımını haritalar üzerinde gösterir. Burada dipnotlarda, Anadolu ağızlarının tabii bir uzantısı olan Rumeli, Azerbaycan ve Irak Türkmen ağızlarındaki eş veya yakın özelliklere de atıflarda bulunur (Karahan, 1996: V).

Anadolu Ağızlarından Manisa, İzmir, Denizli, Aydın, Muğla ile Afyon ve Kütahya'nın birer ilçesinin bulunduğu geniş bir bölgenin ağız yapısını inceleyen 


\section{1)}

Z. Korkmaz, Güneybatı-Anadolu ağızlarını, bazı fonetik ve morfolojik ayrılıklardan hareket ederek, dört ağız bölgesine ayırır. İncelemesinde bu ağızlar arasındaki ayrılıklara geniş şekilde yer vermiştir (Karahan, 1996: XV). Karahan ise, sınıflandırmasında Muğla'yı, Batı Grubu ağızlarının alt grubunda; Afyon, Antalya, Aydın, Balıkesir, Bilecik, Burdur, Bursa, Çanakkale, Denizli, Eskişehir, Isparta, İzmir, Kütahya, Manisa, Uşak ve Ankara (Nallıhan) ile 1. grupta göstermektedir.

Karahan, Batı grubu ağızlarının diyalektolojik yapısı hakkında şunları söyler: Bölgeye yakın zamanlarda Balkanlar'dan, Kafkasya'dan, Türkistan'dan ve Kırım'dan gelerek yerleşen Türk toplulukları kendi ağız özelliklerini korumuş ve yerli halkın dilini etkilememiştir. Ancak doğudan batıdaki büyük şehirlere doğru gelişen iç göçler, Batı Grubu ağızlarında birtakım karışma ve kaynaşmalara yol açmış ve ağız grupları arasındaki farklılıkları derinleștirmiştir. Dolayısıyla Batı Grubu ağızlarını belirleyici temel özellikler, bölgenin kuzeydoğusunda, kuzeydoğu ağızlarının etkisiyle zayıflamıştır (1996: 114).

Karahan, Batı Grubu ağızlarını diğer ağızlardan ayıran başlıca özellikleri on madde halinde siralar:

$\mathrm{Bu}$ ağızlarda ilerleyici benzeşme, gerileyici benzeşmeden daha kuvvetlidir. Bu sebeple tek şekilli birçok ek uyuma tabi olmuştur: varıdı, yaparkan.

Kapalı /é/ > /i/ değişmesi bütün Anadolu ağızlarında görülmekle birlikte bu grupta daha yoğundur: virmek.

/r/ ve /l/ ünsüzleri önündeki ünlü türemesi hadisesi, bu ağızlarda düzenli ve kurallıdır: ilimon, urus.

/g/ ve / $\breve{g} /$ ünsüzleri, iki ünlü arasında ve hece sonunda sızıcılaşır: bağır-, de $\breve{g}-$.

/k/ > /g/, /q-/ > / $\dot{\text { g}}$ / ve /t-/ > /d-/ değişmelerindeki yoğunluk bu ağızlarda fazladır: geçi, $\dot{g} ı$, daş.

Arka ve orta damak /y/ ünsüzü korunmuştur: degiz.

Zamir kökenli teklik 1. ve 2. şahıs ekleri ile bildirme ekleri dar ünlülüdür. $\mathrm{Bu}$ ekler çokluk 2. şahısta $\{-\mathrm{sI} I z\}$ ve $\{-\mathrm{sU \eta JUz}\}$ şeklindedir: gelirim, gelirsiy, gelirsiniz. 


\section{J(৫)}

Çokluk 2. Şahıs iyelik eki ve iyelik kökenli şahıs eki (Doğu grubu ağızlarında olduğu gibi) büzüşme ile yapısını değiştirmemiştir: babayız, geldiniz.

Duyulan geçmiş zaman eki çok şekillidir: olmuş, gelmiş.

Şimdiki zaman eki genellikle geniş ünlülüdür: geliyo, geliye.

\section{Kırcali ve Muğla ağzı}

G. Hazai, Doğu Rodop ve Deli Orman ağızlarını Doğu Rumeli grubu içinde gösterir. Kırcali de, Doğu Rodop Türk ağızları bölgesinde bulunmaktadır. Kırcali bölgesinde yaşayan topluluk kendini Dağlı olarak ifade eder, ancak sorulduğunda kendilerinin sürekli burada yaşadıklarını söylemektedirler. Oysa tarihî veriler Türklerin Rumeli'ye geçişiyle birlikte birçok Yörük (Türkmen) grubunun bu topraklara geldiğini bildirmektedir.

Kırcali ve çevresi Türkiye'ye büyük sayıda göçmen vermiş, ama buna rağmen bölgede çoğunluk olarak varlıklarını sürdürmektedirler. Burada konuşulan ağız Kırcali Ağzı veya Kırcali Dağlı Ağzı (halk ağzında Gırcalı) olarak adlandırılmaktadır (Mehmed, 2006).

Batı Anadolu Bölgesi, eldeki verilere göre Orta Deliorman Bölgesi ağızlarından çok uzak değildir. Kırcali ağzının Batı Anadolu Bölge ağzı ile bağlantısına ilkin, -Meninski'nin, ondan da Gadjanov'un şimdiki zamanla ilgili verilerinden hareketle- M. Adamović dikkat çekmiştir. Ona göre, Kırcali ağzı, sadece şimdiki zamanla bağlantılı değil, bu ağzın diğer özellikleri de Batı Anadolu ağzındakilerle örtüşmektedir (1985: 171-173). Ancak, Adamović bu veriyi yanlışlamamış, burada geçen eki \{-(I)vAr(I)\}, şimdiki zaman eki gibi almıştır (Tulu, 2008: 129-136). Maalesef, Günşen de makalesinde ver- yardımcı fiilini şimdiki zamanda bir ölçüt gibi değerlendirmiştir (2008: 402-470).

Rumeli ağızlarından Kırcali ağzını, Karahan'ın belirttiği on ölçüt esasında Batı Anadolu Bölgesindeki Muğla ağzı örneğinde karşılaştırdığımızda şu ayrılıklar bulunur. Muğla ağzından örnekler, kendi derlemelerimiz ve tez öğrencimizin yaptığı derlemeden alındı (Ünlüsoy, 2004: 47).

Türkiye Türkçesinde kalınlık-incelik uyumuna uymayan bazı ekler Muğla'da uyuma girer: oluyorqan, atınan, yog̉udu, varımış yoğumuş, çoğumuş, sabalān v.b. Ancak: ġoşuncek 'koşunca', gälincäk 'gelince', almē ‘almaya'. 


\section{1)}

Kırcali ağızlarında $\{-q a\},\{-q a n\}$ ve genişletilmiş şekillerde $\{-q a n a\},\{-q a s ı n a\}:$ qaçārqana, ġazāqan, çıqarqan, varqan, gidērke, yaparqā, kesēken, çıqārqan, oynāqana, ġzanqan v.b.

Birleşik fiil çekiminde: varıdı, varmış, olursa, oqurdum, çalışırdıq, ölürse, qaybolursa vb.

\{+ki\} eki ise şu kelimelerde uyuma girer: yandaqı, aşāql; \{+leyin\} eki: sabālan; \{-cAk\}: görcek, alcaq, tutçaq

Muğla ağzında kapalı /é/ ünlüsü yer yer korunmuştur. Örneğin: bél, él, yér, dé, géce, gét, vér, yé, yét vb. Kırcalı ağzında: yimez, ni vb. ancak: leva.

/r/, /l/ ve /ş/ ünsüzleri önündeki ünlü türemesi her iki ağızda da vardır: Kırcali ağzında ilazım, ilezir, erecep, işennik vb.; Muğla ağzında: ilāna, tramazan, ilāzım, ıradıyo, ırahmath vb. ancak, işey.

/g/ ve / $/$ / ünsüzleri, iki ünlü arasında ve hece sonunda sızıcı hale gelir: bağır-, değ-: Muğla ağzında art damak ünsüzü iki ünlü arasında korunmuştur: ġabağa, bucağa, Yatıġan 'Yatağan' (Muğla'nın bir ilçesi); eşeg; fakat dāya vb. Kırcali'de süreklileşme görülür: çocuyu, dāyına, dēy mi, biyenirse, büyüdüyüm vb. ancak: suvan.

/k/ > /g/, /q-/ > / $\dot{\mathrm{g}}-/$ ve /t-/ > /d-/ değişmelerinde. Muğla: geçi, gendi, ġadan 'kadar', $\dot{g} a z ı \dot{g}, \dot{g} ı z ı d m ı s, \dot{g} ı z ;$ ancak keyik ve key- kelimelerinde /k-/ ünsüzü korunmuş̧tur. daş, dänä, däkä, däsdi, dut-, dükä’ttiniz, dabanca vb. Kırcali'de: quyunun, qoltūnun, qutunun, teftere, tiktilē, tiken, dopla, daşlarında, daqınırmış, datl, dırnaqlarınna, yaşıld, davşan.

Muğla ağzında genitif ve iyelik eklerinde /y/ ünsüzü korunmuştur: gelingızıı. Kırcali ağzında bu nazallık görülmez: quyunun, unun, qoltūnun, qutunun, dilinin, gelinin, ayfanın, pādişahın, adamın, qartalın, bubamın. Ancak ünlüden sonra: dünyayın, ardayın, baqlavayın, ablayın, tavayin, ablayin. Muğla'da: depizin içinde, satdıqlāmıı v.b.

Zamir kökenli teklik 1. ve 2. şahıs ekleri ile bildirme ekleri dar ünlülüdür. Bu ekler çokluk 2. şahısta $\{$-sXyXz\} şeklindedir: Muğla: gelirim/n, geliriy/gelirsiy, geliriz, gelirsiyiz. Kırcali'de benzerdir. Yalnız 2. çokluk ekinde iyelik kökenli ek görülür: geliyayız. 


\section{1)}

Çokluk 2. Şahıs iyelik eki ve iyelik kökenli şahıs eki Muğla'da: babayız, geldiniz; Kırcali'de nazallık görülmez: qapunuza, pasportlarınızı, cevizleriniz vb.

Duyulan geçmiş zaman eki Muğla'da çok şekillidir: olmuş, gelmiş, çoğumuş, yog்umuş, hayalatımış. Kırcali'de de çok şekillidir. 1. ve 2. çokluk şahısta örneği gözlemlenmemiştir.

Muğla'da şimdiki zaman kategorisini ifade etmede birçok yardımcı fiil kullanılır. Bu ağızda şimdiki zaman yort-, bat- (< yat), dur-, bar-, gel- gibi yardımcı fiillerle kurulur ve asıl fiile \{-Ip\} gerundiumu gelir: geliyo, yuduyoru, gezip batırī, ǵaynäpdurū, yatıpdurū, gelivatı, gelibatır, gelipbatırı, ġavgasını edibatīla, gälik gälī, gäk gälirin veya gälik gälirin, ölük giderin, gipbarın vb.

Şimdiki zaman eki Kırcali İli ve Çevresi Türk Ağzında diğer ağızlarda görülmeyen çok değişik gramatik yapilar sergiler. Bu eserdeki metinlerden tespit edilen şimdiki zaman ekleri ve çekimleri şunlardır:

1. $\{-\mathrm{Xyo}-\}:\{-\mathrm{XyOm}\},\{-\mathrm{XyOn}\},\{-\mathrm{XyO}\},\{-\mathrm{XyO}\},\{-\mathrm{XyOsUnUz}\},\{-\mathrm{XyOnUz}\},\{-$ XyOlā\}.

2. $\{-\mathrm{yA}\}:\{$-iyam\}, $\{$-iyasin\}, $\{$-iyer $\},\{$ iyaz $\},\{$-iyanız\}, $\{$-iyalar\}.

3. $\{-\mathrm{vAr}-\}$.

4. $\{$-yor\}

\{-A\} eki ile yapılan şimdiki zaman (-Ar olmalı!): dēri, görēriz, gidērsiniz, çekilellē . Olumsuz şekil \{-mAr\}: bilmērim, gitmērsin $\mathrm{vb}$.

Kırcali İli ve Çevresi Türk ağızlarında ver- yardımcı fiili yaygın bir şekilde kullanılmakla birlikte, ek şimdiki zaman eki değildir, çünkü ek, asıl fiilin köküne gelen, gövde teşkil eden bir yardımcı fiildir. Bu tür birleşik yapılarda belirleyici olan unsur zaman ekidir (Tulu, 2008: 129-136).

Örneğin, Muğla'da: yīver- 'yiyip bitirmek': yìveriyōsumuz 'yiyip bitiriyorsunuz', yīverilermiş. Burada fiil gövdesi olarak kalıplaşmış bir yapı söz konusudur. Fiile şimdiki zaman kavramını veren ise sondaki geniş zaman eki \{Ar\}'dır. \{-Ar\} ekinin -ölçünlü dilde de olduğu gibi- geniş zaman yanında şimdiki zaman işlevi de bilinmektedir.

Kırcali: götürvērim, ġoyversin, gitvōri; bişirvēris; gitversiniz; qoyvellē. Ekin yuvarlak şekline örnek: gitvőri 'gidiyor', invőri 'iniyor', qaçyörüz 'kaçıyoruz'. Doğu- 
Rumeli bölge ağzına giren Edirne-Dağlı ağzında da bu şekli görmekteyiz: \{(I) $\operatorname{vAr}(\mathrm{I})\}$

Kırcali ağzında görülen diğer bir şimdiki zaman eki de \{-yor\} ekinden gelişmiştir. Böyle bir gelişme sonucu ortaya çıan şimdiki zamanın çekim tablosu da şöyledir: toplanōrum; döşiyorsun; çıqōru; istiyörüz; gidōrsunuz; doldurollā, kesōrsin ‘kesiyorsun' vb.

$\{-A\}$ ile yapılan şimdiki zaman (Aslında $\{-A r\}$ olmalıdır, çünkü verilen örnekler ekle örtüşmüyor.): bilme:rim, gitme:rsin, de:ri, göre:riz, gide:rsiniz, çekilelle: v.b.

Anadolu ağızlarının sınıflandırılmasında kullanılan ölçütlerde \{-iver\} şekli, diğer şimdiki zaman eklerinin yanında görülmez. Karahan, Korkmaz, Boeschoten (1991: 154) da bu eki, şimdiki zaman ölçüt olarak almamışlardır. Kanımızca şimdiki zaman bahsinde bu ekin ölçüt olarak alınmaya devam etmesi daha önceden sözünü ettiğimiz yanılgıyı devam ettirmekten öte gitmez.

Söz dağarcığı bakımından Muğla ve Kırcali'de şu kelimelerin ortak olması dikkati çeker: issan 'insan', buba, aşāa, aşarı, bora/burē, 'burası', borda/bōda 'burada', evel, orē, ahlät ve alfat 'ahlat, aşılanmamış armut, yaban armudu', ilāna/lāna 'lahana' munar/ munar; tārle, oqaru/ öqaru-oqarı, yörü- 'yürü-', uzman 'o zaman' vb.

Dikkatimizi çeken bir başka şekil, Muğla ağzında görülen bazı fiillerin yönettiği akuzatifli ve datifli şekiller Kırcali'de yoktur. Örneğin, Muğla'da: evi gitmek, evi çıkmak, vb. ġabağa ăgacı astı 'kabağı ağaca astı' vb.

Yine Muğla ağzındaki en belirgin özelliklerden kelime başındaki /f/ > /h/ değişmesi ile kelime içindeki kalın /-q-/ ünsüzünün palatalleşerek kısa bir girtlak sesine dönüşmesi ( ' ) olayı Kırcali'de yoktur: da'll (< daql < tatlı) 'tatlı' ve Hatma 'Fatma' (özel isim).

Bu karşılaştırmalardan sonra M. Mansuroğlu'nun Edirne Ağzında Yapı, Anlam ve Söz Dizimi Özellikleri makalesinde şu sözlerine vurgu yapmak isterim:

Trakya'nın yerli ve göçmen ağıları incelendikçe eski Edirne ağzının Balkan ağızlarına yaklaşan taraflarının gittikçe daha iyi anlaşılacağını sanıyorum. Balkan Türkçesinin Anadolu ağızlarından hangilerine yaklaştığ konusu da ancak bu yolla aydınlanabilir. (1988: 182) 


\section{J(e)}

Mansuroğlu'nun bu sözleri, bu çalışma için de geçerlidir. Dolayısı ile biz de burada, Batı Anadolu bölgesinden Muğla ağzını, Doğu Rumeli Bölgesinden Kırcali ağzı ile karşılaştırarak bu alanda yapılacak araştırmalara bir katkıda bulunmaya çalıştık.

\section{Kaynakça}

Acaroğlu, T. (1984). Rumeli Türk Ağızları Üzerine Türkçe ve Yabancı Dillerdeki Başlıca Araştırmaların Açılamalı Kaynakçası (1904-1981). Halk Kültürü, 4, 13-40.

Adamović, M. (1985). Konjugationsgeschichte der türkischen Sprache. E.J. Brill.

Ali, N. (2004). Bulgaristan Kırcaali Bölgesi Türk Ağızları. Erciyes Üniversitesi, Sosyal Bilimler Enstitüsü, Türk Dili ve Edebiyatı Anabilim Dalı. (Yayımlanmamış Yüksek Lisans Tezi)

Atilla, C. (1967). Bulgaristan'da Türk Dili. Türk Kültürü̈, 59, 847-852.

Ayyıldız, F. (1976). Razgrad Ağzı. İstanbul Üniversitesi, Edebiyat Fakültesi, Türk Dili ve Edebiyatı Bölümü. (Yayımlanmamış Lisans Tezi)

Baski, İ. (2009). Otuz Yıl Öncesi Deliorman Ağızlarının Şimdiki Zaman Ekleri Üzerine. In Terzi, A. \& Durkun, A. (Eds.), Türkiye Türkçesi Ağız Araştırmaları Çalıştayı Bildirileri, 25-30 Mart 2008 Şanlıurfa (pp. 112-128). Türk Dil Kurumu Yayınları.

Bernard, R. (1962). Razlog Dialektinin Ağız Özelliği. Balkan Dilbilimi, 4, 205-229.

Boev, E. (1968). Bulgaristan'da Türk Diyalektolojisi İle İlgili Çalışmalar. In XI. Türk Dili Kurultayinda Okunan Bilimsel Bildiriler, Ankara, 8-10 Temmuz 1966 (pp. 171-178). Türk Tarih Kurumu Basımevi.

Boev, E. (1980). Güney-Batı Bulgaristan Türk Ağızlarında Gelecek Zaman. In I. Millı̂ Türkoloji Kongresi, İstanbul, 6-9 Şubat 1978, Tebliğler (pp. 126-139). Kervan Yayınları.

Çebi, İ. S. (1986). Güneydoğu Bulgaristan Türk Ağızları. Gazi Üniversitesi, Sosyal Bilimler Enstitüsü, Türk Dili ve Edebiyatı Bölümü. (Yayımlanmamış Yüksek Lisans Tezi).

Dallı, H. (1991). Kuzeydoğu Bulgaristan Türk Ağızları Üzerine Araştırmalar. Türk Dil Kurumu Yayınları.

Dallı, H. Milino (Keremedin) Köyü Türk Ağzı, Kuzeydoğu Bulgaristan’ın Omurtag (Osmanpazarı) Bölgesi Türk Ağızlarından Karşılaştırmalı Örneklerle Ses Bilgisi, Yapı Bilgisi, Söz Dizimi ve Metin Derlemeleri. Genişletilmiş 3. Baskı. (Baskıda) 


\section{ग(৫)}

Eckmann J. \& Mansuroğlu, M. (1959). 1959 Y1lı Trakya Diyalektolojisi Gezi Raporu. İstanbul Üniversitesi Edebiyat Fakültesi Türk Dili ve Edebiyatı Dergisi, 9, 113-118.

Eckmann, J. (1941). Die türkische Mundart von Warna. Körösi Csoma-Archivum, 3, 144-214.

Eckmann, J. (1950). Razgrad Türk Ağzı. In Eren, H. (Ed.), Türk Dili ve Tarihi Hakkında Araştırmalar (pp. 1-25). Türk Tarih Kurumu Basımevi.

Eckmann, J. (1962a). Kumanova Türk Ağzı. In Eckmann, J. et al. (Eds.), Németh Armağanı (pp. 111-144). Türk Dil Kurumu Yayınları.

Eckmann, J. (1962b). The Turkish dialects of Edirne. In Poppe, N. (Ed.), American Studies in Altaic Linguistics (pp. 46-69). Indiana University Publication.

Eckmann, J. (1988). Dinler (Makedonya) Türk Ağzı. Türk Dili Araştırmaları Yıllığı Belleten 1960, 189-204.

Gadjanov, D. (1912). Vorläufiger Bericht über eine im Auftrag der BalkanKomission der kais. Akademie der Wissenschaft in Wien durch Nord-Ost Bulgarien unternommene Reise zum Zwecke von türkischen Dialekt-Studien. Anzeiger der phil.- hist. Klasse der Akademie der Wissenschaften in Wien Jahrgang 1911, 5, 1-8.

Guzev, V. (1962). Opisanie turetskogo govora sela Krepça, Tirgoviştenskogo okruga v Bolgarii sp. Balkansko Ezikoznanie, 5(2), 57-85.

Gülensoy, T. \& Alkaya, E. (2003). Türkiye Türkçesi Ağıları Bibliyografyası. Akçağ Yayınları.

Gülensoy, T. (1981). Anadolu ve Rumeli Ağızları Bibliyografyası (Anadolu-Kıbrıs-SuriyeIrak-Bulgaristan-Yugoslavya ve Romanya Türk Ağılarl). Kültür ve Turizm Bakanlığı Yayınları.

Günşen, A. (2008). Doğu-Trakya Ağızlarının Şekil Bilgisini Belirleyen Temel Özellikler. Turkish Studies, 3(3), 402-470.

Hazai, Gy. (1960). Rodop Türk Ağızları. In VIII. Türk Dil Kurultayında Okunan Bilimsel Bildiriler 1957 (pp. 127-130). Türk Dil Kurumu Yayınları.

Hazai, Gy. (1971). Anadolu ve Rumeli Ağızlarının Tasnifi Üzerine. In Şiralieva, M. Ş. (Ed.), Voprosi Tyurkologii (pp. 84-86). Akademika AN Azerbaycan SSR.

Karahan, L. (1996). Anadolu Ağızları Sinıflandırılması. Türk Dil Kurumu Yayınları.

Karaörs, M. (2000). Kuzeydoğu Anadolu (Trabzon ve Yöresi) ve Batı Rumeli Türk Ağızlarının Ortaklığı ve Akrabalığı. In Çiçek, K. et al. (Eds.), Trabzon Tarihi Sempozyumu Bildirileri, 6-8 Kasim 1998, Trabzon (pp. 89-98). Trabzon Belediyesi. 


\section{ग(৫)}

Korkmaz, Z. (2008). Anadolu ve Rumeli Ağızlarında Etnik Yapı Ayrılıklarından Kaynaklanan Ses ve Şekil Bilgisi Zenginliği Üzerine. In Arıkoğlu, E. (Ed.), Prof. Dr. Ahmet Bican Ercilasun Armağanı (pp. 131-139). Akçağ Yayınları.

Korkmaz, Z. (2010): Anadolu ve Rumeli Ağızlarının Dayandı̆̆ı Temeller. Türk Dili Araştırmaları Yıllığı Belleten 2007/1, 87-110.

Kowalski, T. (1933). Les Turcs et la langue turque de la Bulgarie du nord-est. Nakł. Polskiej Akademji Umiejętności.

Kowalski, T. (1934). Osmanisch-Turkische Dialekte. Enzyklopädie des Islam, 4, 9911011.

Mansuroğlu, M. (1988). Edirne Ağzında Yapı, Anlam ve Söz Dizimi Özellikleri. Türk Dili Araştırmaları Yıllı̆̆ı Belleten 1960, 181-187.

Mehmed, N. S. (2006). Bulgaristan Kırcali İli ve Çevresi Türk Ağzı. Trakya Üniversitesi, Sosyal Bilimler Enstitüsü, Türk Dili ve Edebiyatı. (Yayımlanmamış Yüksek Lisans Tezi).

Mollova, M. (1962). Les ga-dialectes turcs dans les Balkans et leur rapport avec les langues turc. Balkansko Ezikoznanie, 4, 239-306.

Mollova, M. (1999). Balkanlarda Türk Ağızlarının Tasnifi. Türk Dili Araştırmaları Yıllığı Belleten 1996, 167-176.

Moskov, M. (2003). Doğu Rodop Türk Ağızlarının Sözlüğü. Türk Dil Kurumu Yayınları.

Nemeth, Gy. (1983). Bulgaristan Türk Ağızlarının Sınıflandırılması Üzerine. Türk Dili Araştırmaları Yıllığı Belleten 1980-1981, 113-167.

Tulu, S. (2008). Anadolu ve Rumeli Ağzında \{-i verir\} Yapısı. Karadeniz Araştırmaları, 5(19), 129-136.

Ünlüsoy, M. (2004). Muğla Düğerek Ağzının Gramer Özellikleri. Muğla Sitkı Koçman Üniversitesi, Türk Dili ve Edebiyatı. (Yayımlanmamış Lisans Tezi). 